Rohmad, Ali. 2009. Kapita Selekta Pendidikan. Yogyakarta: Teras.

Rosyadi, Khoiron. 2004. Pendidikan Profetik, Yogyakarta: Pustaka Pelajar.

Purwatiningsih, Siti. "Peningkatan Prestasi Belajar Biologi Siswa Kelas X.1 SMA N 2 Salatiga

Melalui Metode Proyek Dengan Penilaian Presentasi Dan Poster", Jurnal LIK

(Lembaran Ilmu Kependidikan): Journal Of Educational Research.

Saodi, Ondi dan Aris Suherman. 2012. Etika Profesi Keguruan, Bandung: PT. Refika Aditama. Sugiyono. 2016. Metode Penelitian Kuantitatif, Kualitatif, dan Kombinasi (Mixed Methods), Bandung: Alfabeta.

2010. Undang-undang RI Nomor 14 Tahun 2005 \& Peraturan Pemerintah RI Nomor

74 Tahun 2008 Tentang Guru Dan Dosen, Bandung: Citra Utama.

\title{
EMPOWERING ACADEMIC WRITING SKILLS IN MILLENNIAL ERA: THE ROLE OF ENGLISH PROGRAM FOR BIDIKMISI STUDENTS
}

\author{
Sri Wahyuningsih \\ IAIN Kudus \\ Kudus, Indonesia \\ wahyuningsih@stainkudus.ac.id
}

\begin{abstract}
This study aims at exploring how BIDIKMISI students at the State Institute for Islamic Studies (IAIN) Kudus perceive the empowerment of their academic writing skills through English programs undertaken by the campus. The study anchors in a qualitative research. Personal interviews, observation and documentation were used to gather data. The result reveals that the strategies and ways of empowering academic writing cover developing cognitive skills of students by giving them academic literacy, activities of problem solving, and innovation that will attract them to use writing as systems of representation and communication. Another way of empowering academic writing done by lecturers is by collaborating to other English lecturers particularly those who teach Reading in enhancing the academic writing skills of students at IAIN Kudus. Thus, the role of English programs is considerably meaningful for the acquisition of English language skills of BIDIKMISI students particularly in academic writing skills. Furthermore, they are able to elicit a number of materials and information related to academic writing including writing foundations, writing stages, writing elements, accuracy in writing, researching and writing, academic reality, and articles publication. Interestingly, they are pursued to do a research and write journal articles. This study suggests that lecturers should actively use technology and social media in millennial era such as Facebook, Blog, Instagram, and Youtube to engage students in the process of teaching academic writing.
\end{abstract}

Keywords: Academic Writing, BIDIKMISI Students, English Programs, Millennial Era

\section{Introduction}

English is presumably considered as a foreign language in Indonesian context. It requires area of pedagogy demanding several aspects comprising of culture, socio cultural aspect, psychology, economy, dialects, and so forth. In this matter, English has different pattern and style from Indonesian as a national language in Indonesia and vernacular language as a mother tongue. This difference could be seen from both in spoken and written ways. Regarding it, grammar or structure plays an important role in spoken and written ways. In term of academic writing, it is different from creative writing and personal writing where they are considered as informal writings in which slang, abbreviations, and incomplete sentences may be used (Oshima, A., \& Hogue, A., 2007, p.7). In accordance with it, academic writing is formal, so it is better not to use slang or contractions. In addition, writers are suggested to write complete sentences and to organize them in a certain way. 
In line with the academic areas particularly in writing, students are badly demanded to have an academic writing skill in which those who are not native speakers of English mostly have problems or challenges in the written demands of their courses. Besides learning academic writing, they are enhanced to acquire new conventions of style, referencing and layout (Bailey, 2006., p. vii). Moreover, another aspect that becomes the central to the mastery of academic writing is the development of discourse competence for the novice writer. This includes the knowledge of how to build cohesion and coherence in a text and the ability to integrate different types of knowledge in order to produce extended written discourse in appropriate and accurate ways.

Besides discourse competence, another fundamental aspect in the writing process is grammatical competence which refers to the knowledge of grammatical rules and lexical items in the process of writing. Further, social-cultural models may give the input of developing the academic writing skill. These cover creating a well environment comprising of more knowledgeable writers as models, advocating writing approximation as success, applying supportive dialogue that shapes the learners' thinking as they write, developing strategies of planning in creating test, using editing and revising strategies, publishing and sharing writing with real environment and audiences (Kraayenoord, Miller, \& Moni, 2009, p. 25).

Numerous studies related to the academic writing skills have been previously conducted by researchers. A professional learning project, write ideas, can be one of the alternatives of teaching writing to students with learning difficulties in inclusive English (Kraayenoord et al., 2009, p. 23). Moreover, the challenges mostly found by students from South Africa with limited exposure to English covers the tendency of making similar errors relating to writing and argument style and to misplaced vocabulary (Banda, 2004, p. 11). Then, the challenges in English learning are found by Arabic students including the linguistic, cultural, educational, political and personal challenges (Lakshmi, 2013, p. 49).

Likewise, students at IAIN Kudus especially BIDIKMISI students may encounter a number of challenges in learning academic writing skills. In line with it, the role of English Program held by IAIN Kudus is considerably meaningful for students' English improvement particularly in empowering academic writing in millennial era. In other words, they are guided through processes of writing to produce well-structured, appropriately developed writings. This article may differ from the previous studies considering that the students of IAIN Kudus have various background of language in their society comprising of Indonesian and Javanese which have various dialects. In accordance with it, this paper mainly describes the ways of empowering academic writing in millennial era skills through English Program held by IAIN Kudus for BIDIKMISI Students.

\section{Related Literature}

\section{Writing in Academic Context}

Academic writing is considerably linked with the level of context of situation and context of culture (Pineteh, E. A., 2014, p.13). With this regard, university students especially those who get a scholarship at IAIN Kudus are supposed to acquire academic writing to be familiar with university culture, comprehend discourses, construct power relations, individual identities, and other disciplines of knowledge. Further, academic writing should be taught through courses such as English program held by IAIN Kudus for BIDIKMISI students from various departments. It is expected that students will be knowledgeable with discipline-specific writing and the development of their cognitive aspect. Additionally, writing is a crucial skill which is needed in several contexts throughout life. 
There are a number of elements that need to be taken into account in academic writing contents. These cover beliefs which deals with establishing belief that becomes a job of the entire university, persuasion which deals with how writers persuade the readers through his or her own writing, evidence which deals with how writers create evidence or facts to support their writing, documentation which deals with how writers provide their readers with a complete account of where they got the information, ideas, and proofs by showing footnotes, endnotes, references, bibliographies, and literature searches, objectivity which deals with the way in which writers seek the truth is expected to be impartial and objective, relativity which refers to the way how writers make academic assertions is supposed to pay attention to the qualifying words (maybe, perhaps, possibly), balance which deals with the way how writers use balance phrases such as on the other hand, on one hand, in other words (Fulwiler, T., 2002, p. 58).

From the above elaborations, it could be deduced that writing in academic context plays paramount and specific rules which are different from writing in general context as personal writing. In academic writing, there are some kind of structures comprising of beginning, middle and end. Then, in academic writing, there is a rule that writers are supposed to support their ideas and opinion by connecting it what the previous writer wrote about the case. Moreover, citing sources from other writers becomes a main aspect since it indicates that the writer have read a lot of literatures and integrate the case and perspectives. Additionally, in academic writing, the writers are considered to pay attention to the references conventions, punctuation, and grammar. In other words, academic writing is a special writing prescribing its own rules, guidelines, and practices.

\section{Writing Process}

Writing is an ongoing process and it is not one-step action. Indeed, an activity of writing belongs to productive skills which require a number of processes. According to Jones (2006), the focus of writing was on two major views: An expressive view which was free and creative and a heavy influence of a cognitive view of writing. Meanwhile, Heald-Tayler (1986, cited in Jarvis, 2002) asserts that process of writing is an approach which encourages learners to communicate their own written messages while simultaneously developing their literacy skills in speaking and reading rather than delaying involvement in the writing process, as advocated in the past, until students have perfected their abilities in handwriting, reading, phonetics, spelling, grammar and punctuation. There are a number of steps in writing. First, prewriting which refers to create ideas. Second, organizing ideas into a simple outline. Third, writing a rough draft. Fourth, revising and editing. Fifth, writing a final copy (Oshima, A., \& Hogue, A., 2007, p.15). In line with the process of writing, Zemach, D. E., \& Rumisek, L. A. ( 2003, p.3 ) elaborates steps in writing more detail. These cover prewriting which inludes choosing a topic, gathering ideas, and organizing ideas. Then, drafting which deals with writing paragraph or essay from start to finish. Next, reviewing and revising structure and content by checking what we have written. Finally, rewriting which includes making improvement to the structure and content, proofreading the text, and making final corrections.

\section{Challenges of Learning Academic Writing}

There have been challenges in learning writing since English is not the students' mother tongue. One of the challenges is students are not familiar with the conventions of academic writing in English. Besides, they fail to show their arguments in acceptable and formal ways (Banda, F., 2017, p. 13). Other challenges in learning academic writing are students show high number of mistakes in spelling, they show lack of experience in writing English and lack of 
exposure in English, students show lack of discourse patterns, structures, and the lack of English teaching practices in students' schooling previously. This is in accordance with Pineteh, E. A. (2013, p. 15) asserting that the previous schooling experience of students will give impacts on their academic performance particularly in academic writing. Furthermore, a better quality of academic writing acquired by students in higher education presumably enables them to think and read critically, interprets, and argues statements in order to build social identities.

Similarly, the above challenges of learning writing are also reported explicitly by Khan, I., A., (2011, p. 71) describing that most students in Sudan commonly find problems in writing especially related to syntactic errors in their composition of English writing. The syntactic errors showed by them include structures, subject-verb agreement, and tenses. In addition, students have problems in expressing themselves competently and arguing their ideas of writing in critical ways. Different from the previous elaborations indicating the challenges of academic writing faced by students, Lakshmi, Bh.V.N. (2013, p. 50) explores the challenges of empowering academic writing faced by English teachers. These cover the deficiency in English language curricula designed by schools and universities, a discrepancy between the standard of syllabus and the students' needs that becomes main challenges, conventional teaching methodology, and poor facilities and so on. Additionally, she emphasized that students may have lack of information in accordance with the university where they study; students may have problems in proper language environments and lack of motivation and attitudes in learning academic writing.

\section{English Program for Bidikmisi Students}

English program is held by IAIN Kudus for the purpose of the better English development among BIDIKMISI students. BIDIKMISI is a realization of the government program to improve the quality of education quality and break the poverty chain in Indonesia. The BIDIKMISI program was launched by the Ministry of National Education in 2010. With regard to this, this kind of scholarship guarantees all recipient students to be free of semester fees and get a living or allowance per month. IAIN Kudus is one of the State Islamic Institute included in the list of BIDIKMISI program targets. Specifically, the programs of BIDIKMISI at IAIN Kudus are organized by Ma'had Al- Jami' ah of IAIN Kudus. In the forum of Ma'had Al- Jami' ah, BIDIKMISI students can be familiar with their friends, learn organization, interact with others, train leadership, and build networks with others. In order to improve the English skills among bidikmisi students, Ma'had Al-Jami'ah IAIN Kudus provide a number of English programs including Listening, English Debate, Academic Writing, drama, Moderator and speaker in English, Pronunciation, Translation, Reading, and so on. In term of writing, the academic writing class plays an essential role in developing students' writing skill in English. This program was held for a month (July to August).

\section{Research Methodology}

This study belongs to a descriptive qualitative research. In order to gather data, the writer interviewed students comprising of five female students and five male students who get BIDIKMISI scholarship from various departments at IAIN Kudus related to the English Program held by IAIN Kudus including the benefits of joining academic writing class, the challenges of and opportunities of learning academic writing, and so on. In addition, the observation was conducted both to see and describe the teaching and learning process in academic writing class through English program held by IAIN Kudus. Moreover, documentation was done by the writer to capture the experience of teaching academic writing for BIDIKMISI students at IAIN Kudus. 


\section{Finding and Discussion Empowering Academic Writing Skill in Millennial Era}

It has been previously mentioned that empowering academic writing skill for students in millennial era becomes an important issue. Considering this, lecturers can empower it through several ways by engaging students in academic writing class, redesigning academic development curricula particularly in academic writing in such a way that they are more responsible to the need of their students. Furthermore, English lecturers are supposed to develop cognitive skills of students by giving them academic literacy, activities of problem solving, and innovation that will attract them to use writing as systems of representation and communication. Another way of empowering academic writing done by lecturers is by collaborating to other English lecturers particularly those who teach Reading in enhancing the academic writing skills of students at IAIN Kudus.

Other ways of empowering academic writing skill for students are fostering intensive academic reading and writing activities which give the students experiences with different writing challenges by exploring critical thinking on academic writing exercises. With this regard, lecturers should realize their identity as a facilitator focusing on a continuous developmental process through providing the academic culture of reading and writing. Moreover, using different strategies to increase a warm atmosphere among the students are crucial for lecturers. This can be achieved by recognizing social and learning needs in the process of academic writing teaching (Witteman, 1992, p. 16). Additionally, lecturers can encourage students to sharpen their receptive skills such as listening and reading in order to gain successful productive skills including speaking and writing, lecturers are expected to pursue their students to apply reference management tools properly in quoting a number of references comprising of books, journal articles, and so forth. Mendeley and Zotero programs are the examples of reference management tools. Reference management, the storage, organization, and use of references, is a crucial element of scholarly communication (Melles \& Unsworth, 2015, p. 249).

\section{Roles of English Program for Bidikmisi Students}

The role of English program is beneficial for BIDIKMISI students. There have been numerous English programs designed by Ma'had Al-Jamiah IAIN Kudus including Training of Academic Writing, Translation, Public Speaking, English Debate, Drama, Pronunciation, Morphology, Reading, Listening and so on. Based on the interview, in accordance with training of academic writing, its role is crucial for developing students' skill in academic writing. These cover:

a. Students are able to comprehend structure, components and styles in academic writing. Structure and styles are crucial in writing. In this matter, students of Bidikmisi at IAIN Kudus become more familiar with structures and components in academic writing during joining the training of Academic Writing. It has been stated by one of the students of bidikmisi below:

"Before joining training of academic writing held by Ma'had Al Jamiah IAIN Kudus, I haven't known the structure and components needed in academic writing. Interestingly, I now become familiar with styles and components in academic writing after joining the English program at IAIN Kudus. Besides, I know the theories related to academic writing. Further, I have known the steps in writing including prewriting, drafting which deals with writing paragraph or essay from start to finish. Next, reviewing and revising structure and content 
by checking what we have written. Finally, rewriting which includes making improvement to the structure and content, proofreading the text, and making final corrections" (Dora, October 2018).

b. Students are able to know types of sentences and how to plan a paragraph Knowing several types of sentences is beneficial in academic writing. By joining the training of academic writing class, students of Bidikmisi at IAIN Kudus from various departments become familiar more about simple sentences, complex sentences, and compound sentences. Further, this knowledge will be applied in planning paragraphs in academic writing. Thus, they can write English Essay using various types of sentences. It has been revealed by the student of Bidikmisi:

"In fact, planning a paragraph requires knowledge of types of sentences. In this activity of writing, we should be able to write using simple sentences, compound sentences, and complex sentences. All of them should be written appropriately based on the context of situation. By joining the training of academic writing, I become know more about sentences and paragraphs in academic writing" (Ghofur, October 2018).

c. Students are able to know the importance of unity in cohesion and coherence in academic writing. Unity is an essential element of building a good paragraph. In order to achieve it, the writer should consider cohesion and coherence in academic writing.

d. Students are able to acquire editing and revising text. In order to produce a good text, the process of editing and revising is needed.

e. Students are able to write an essay: Introductory Paragraph, Body Paragraphs and Concluding Paragraph

f. Students are able to elicit a number of materials and information related to academic writing including writing foundations, writing stages, writing elements, accuracy in writing, researching and writing, academic reality, and articles publication.

g. Students are encouraged to do a research and write journal articles. In the end of joining academic writing class, students of bidikmisi at IAIN Kudus are pursued to do a mini research and write a journal article.

\section{Conclusion}

To conclude, academic writing plays crucial and specific rules which are different from writing in general context as personal writing. In academic writing, there is a rule that writers are supposed to support their ideas and opinion by connecting it what the previous writer wrote about the case. With regard to this, students who get BIDIKMISI scholarship need to acquire academic writing considering that they have potentials. In order to actualize it, Ma'had Al Jamiah IAIN kudus held English Programs particularly to empower academic writing in millennial era. The strategies and ways of empowering academic writing cover developing cognitive skills of students by giving them academic literacy, activities of problem solving, and innovation that will attract them to use writing as systems of representation and communication. Another way of empowering academic writing done by lecturers is by collaborating to other English lecturers particularly those who teach Reading in enhancing the academic writing skills of students at IAIN Kudus. Further, students are fostered by intensive academic reading and writing activities which give the students experiences with different writing challenges by exploring critical thinking on academic writing exercises. As a result, the role of English programs is considerably meaningful for the acquisition of English language skills of BIDIKMISI students particularly in academic writing skills. This study suggests that lecturers should actively use technology and social media in millennial era such as Facebook, Blog, Instagram, and Youtube to engage students in the process of teaching academic writing. 


\title{
References
}

Bailey, S. 2006. Academic Writing: A Handbook for International Students Second Edition. London: Routledge Taylor and Francis Group

Banda, F. 2017. Challenges of Teaching Academic Writing Skills to Students With Limited Exposure to English (South Africa), Alexandria, Va: TESOL.

Fulwiler, T. 2002. College Writing: A Personal Approach to Academic Writing. Porthsmouth: BoyntonCook Publisher

Jones, S. J. 2006. Blogging and ESL writing: A case study of how students responded to the use of weblogs as a pedagogical tool for the writing process approach in a community college ESL writing class. Austin: The University of Texas

Jarvis, D. J. 2002. The Process Writing Method. The Internet TESL Journal, VIII (7). http://iteslj.org.

Kraayenoord, C. E. V. A. N., Miller, R., \& Moni, K. B. 2009. Teaching writing to students with learning difficulties in inclusive English classrooms: Lessons from an exemplary, English Teaching: Practice and Critique, 8 (1), 23-51, http://education.waikato.ac.nz/research/files/etpc/files/2009v8n1 art2.pdf

Khan, I., A., 2011. Challenges of Teaching/Learning English and Management. Global Journal of Human Social Science, 11 (8), 69-78

Lakshmi, Bh.V.N. 2013. Challenges in Teaching Language and Literature: An EFL Perspective. IOSR Journal Of Humanities And Social Science, 15 (6), 49-53

Melles, A., \& Unsworth, K. 2015. Examining the Reference Management Practices of Humanities and Social Science Postgraduate Students and Academics. Australian Academic \& Research Libraries, 46(4), 250-276. https://doi.org/10.1080/00048623.2015.1104790

Oshima, A., \& Hogue, A. 2007. Introduction to Academic Writing Third Edition, New York: Pearson Education

Pineteh, E. A. 2014. The Academic Writing Challenges of Undergraduate Students : A South African Case Study, International Journal of Higher Education, 3(1), 12-22. https://doi.org/10.5430/ijhe.v3n1p12

Witteman, C. 1992. Competence and performance in belief revision, 1-28

Zemach, D. E., \& Rumisek, L. A. 2003. Academic writing from Paragraph to Essay. Oxford: Macmillan

\section{THE ENGLISH MASTERY OF PATI TOURISM AMBASSADOR FINALISTS IN PROMOTING TOURISM OBJECTS}

\author{
Suciati \\ IAIN Kudus \\ Kudus, Central Java, Indonesia \\ suci@stainkudus.ac.id
}

\begin{abstract}
In millennial era, English is used in all aspects including tourism. It is very needed to promote tourism objects. So, English competence should be mastered by Tourism ambassadors. This research aims to know (1) the opinion of 2018 Pati tourism ambassador finalists about the use of English for promoting Pati tourism objects, (2) their English mastery, (3) their difficulties in promoting the tourism object using English and (4) their ways to improve their English mastery. This qualitative research used observation, documentation and interview. The samples were 20 finalists. Based on the analysis, there are four results. First, most of them argued that the use of English for promoting Pati tourism object is very important because it can help the tourists to understand the information
\end{abstract}

